\title{
Law Reviews as Cultural NarRative
}

\author{
DONNA GRESCHNER
}

TABLE OF CONTENTS

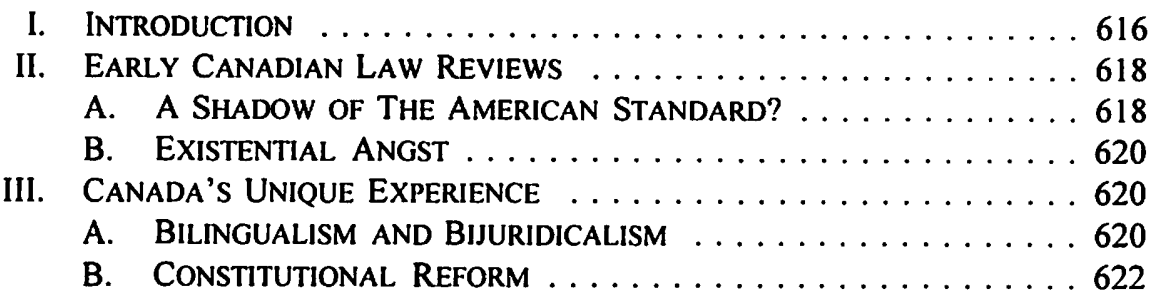

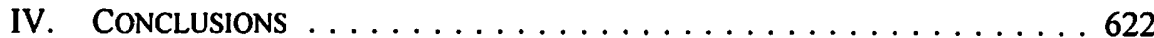

No one in this country needs to be reminded that the word "Canadian" is a difficult concept to describe.'

\section{INTRODUCTION}

When I received the invitation from the editors of the Alberta Law Review to reflect upon university-based law reviews, I thought immediately of the most famous critique published about American ones. I refer, of course, to Fred Rodell's diatribe, "Goodbye to Law Reviews," published in $1936 .{ }^{2}$ I read it many years ago, as a bored law student thirsting for a short and witty article to relieve the tedium of studying trusts. With the present occasion in mind, I dug it out of the library again.

Many of you will be familiar with the essay. Rodell announces that he will no longer write for law reviews, and, in three infamous sentences, tells us why. Let me quote: "There are two things wrong with almost all legal writing. One is its style. The other is its content." With respect to style, Rodell castigates law reviews for "long sentences, awkward constructions and fuzzy-wuzzy words." "4 Thickets of footnotes spring like weeds around each sentence, and student editors apparently despise conviction and humour. With respect to content, Rodell launches an even more scathing attack. Although, he says, "law is supposed to be a device to serve society... [with] a job to do in the world,"s he could find barely any evidence of this mission in law reviews. They did not discuss important problems of the day and contribute to solutions. Rather, law reviews stuffed their pages

Professor, College of Law, University of Saskatchewan; Faculty Editor, Sask. L. Rev. (1997-2002). This paper was presented to the session "The Role and Future of the Law Review" at the Annual Meeting of the Canadian Association of Law Teachers, 28 May 2000. Edmonton. Alberta. Thanks to Dick Risk and David Schneiderman for nurturing my interest in legal history.

G. Parker, "Editorial" (1978) I Can. J. Fam. L. I at 1.

F. Rodell, "Goodbye to Law Reviews" (1936) 23 Va. L. Rev. 38.

Ibid.

Ibid. at 39.

Ibid. at 42. 
with "fluffy filling" on obscure and technical matters of interest only to legal navelgazers. In Rodell's opinion,

it would be hard to guess, from most of the stuff that is published in the law reviews, that law and the lawyers had any other job on their hands than the slinging together of neat (but certainly not gaudy) legalistic arguments and the building up, rebuilding, and sporadic knocking down of pretty houses of theory foundationed in sand and false assumptions.'

Rodell's essay offered exactly what the contemporary law review lacked - conviction, humour, and concision stripped of footnotes.

As I reread the essay, I confess to becoming agitated by one paragraph. To illustrate his point about the irrelevancy of law reviews, Rodell gives titles of articles he considers worthless. The very first is "The Rule Against Perpetuities in Saskatchewan." Rodell's sarcasm implies that few people, if any, ought to care about the property law of a place so remote and marginal. His jab awakened my usually dormant Saskatchewanian loyalties. I noticed that when Rodell derisively dismissed law reviews in 1936, the Saskatchewan Bar Review, which would later become the Saskatchewan Law Review, was only a few months old. ' A hasty search of adjoining library shelves assured me that if such an article did clutter a journal, it had not been published in Saskatchewan. Either Rodell had imagined the article, or someone from outside of Saskatchewan had taken interest in the province's law about perpetuities. (I confess that the latter possibility gave me comfort). Furthermore, as I read the first slender issue of the Saskatchewan Bar Review, I puffed slightly with pride in discovering its editorial foresight. Long before American reviews began faddishly meditating on the hermeneutics of lawyer jokes, this lowly review had published a speech that referred to jokes about lawyers as indicating negative public attitudes toward the profession. ${ }^{10}$

It is telling that in reflecting on Canadian law reviews, my first impulse was to turn to an American essayist, publishing in an American law review, and then bristle with typical Canadian defensiveness upon finding a hint of criticism directed at the Canadian experience. Indeed, after finishing my search of the Saskatchewan Bar Review for Rodell's perpetuity example, I felt like such a stereotypical Canadian that I almost did not relate the incident to you today. But I will tolerate the embarrassment of exposing my reaction because the incident illustrates a broader point.

\section{Ibid. at 43.}

Ibid. at 42. However. on the 25th anniversary of the article's publication. at the invitation of the editors of the Virginia Law Review, he wrote a follow-up in which he declared that law review style, not substance, was "what [was] wrongest about them." See F. Rodell. "Goodbye to Law Reviews Revisited" (1962) 48 Va. L. Rev. 279 at 287.

× Supra note 2 at 42.

" Rodell's essay appeared in the issue of the Virginia Law Review dated November 1936, while the first issue of the Saskatchewan Bar Review is dated March 1936. The Saskatchewan Bar Review changed its name to the Saskatchewan Law Review in 1967, upon publishing volume 32. In the intervening 31 years, it evolved from a practitioner's newsletter that contained scholarly notes to a scholarly journal that published occasional news about practitioners. 


\section{Early Canadian law Reviews}

\section{A. A Shadow OF The American Standard?}

As with most Canadian cultural phenomena, university-based law reviews ${ }^{\prime \prime}$ have always risked being measured by an American standard and swamped by their American counterparts. American legal publications are a great sea of printed words in which the Canadian law review makes barely a drop. We are not alone in feeling small. The law reviews of other anglophone countries, such as the United Kingdom and Australia, are also overshadowed by the American multitudes. This preponderance of American reviews is not simply a function of the larger American population or the proportionately greater number of law schools in the United States. It is also a matter of attitude. Almost without exception, Americans regard publishing a law review as a necessary attribute of any school worth its salt. ${ }^{12}$ Their law schools often publish more than one journal each, partly because they view law review experience as having such merit that as many students as possible must work as editors. American law schools have faith. They believe in the inherent dignity and worth of law reviews.

Moreover, an additional factor contributes to the dominance of American law reviews: they came first. When Canadian law schools began to publish law reviews, the American examples already sat like a brooding omnipresence in the libraries, ready to shape all entrants into the field. ${ }^{13}$ The Harvard Law Review appeared in 1887, and the Yale Law Journal in 1891, well before Saskatchewan and Alberta became provinces, let alone established law schools at their universities at, respectively, Saskatoon and Edmonton. In 1936 when the student-run law review had ossified its practices sufficiently to give Rodell fertile ground for critique, the only Canadian student-run journal was the fledgling Alberta Law Quarterly, published by law students at the University of Alberta. In its infancy, having begun in 1934, it would last only a decade. ${ }^{14}$ The year 1936 also saw the first issue of the Saskatchewan Bar Review, an initiative of several unemployed practitioners who received assistance from Dean Cronkite at the College of Law, University of Saskatchewan. The college had merrily operated for over two decades without feeling,

"I use the term "university-based law review" as a loose rubric for law reviews that law schools publish without a professional association or commercial operation controlling, underwriting, or otherwise influencing the publication. For example, with this definition the Saskatchewan Law Review is a university law review, while the Canadian Bar Review is not, even though its editor is a professor.

12 The high water mark of this attitude may well be the sentiments expressed in $\mathbf{H}$. Westwood, "The Law Review Should Become the Law School" (1945) 31 Va. L. Rev. 913.

13 Or, perhaps I should say more precisely the Harvard example. Rodell, supra note 2 at 44 , complains that reviews "have all been sucked into a polite little game of follow-the-leader with the Harvard Law Review setting the pace."

I4 Volume 1 of the Alberta Law Quarterly is dated 1934. A brief, unpaginated foreword indicates that it was published by the law students of the University of Alberta. Volume 5 is dated 1942-45. On its last page the editor pleads with lawyers to pay their subscriptions, promising that more issues will follow, but not when: M.M. Macintyre, “To Our Subscribers and Others"(1942-45) 5 Alta. L.Q. 252. The editor was wise not to commit to a publication date because the Quarterly never published again. In 1955, ten years later, students began the Alberla Law Review with W.A. Stevenson, who would eventually sit on the Supreme Court of Canada, as its first editor. 
apparently, any need to publish a journal. However, Cronkite supported the dreams of the enthusiastic young lawyers, and after the editors enlisted to fight in World War II, the college assumed primary responsibility for their journal. ${ }^{\text {s }}$ In 1936 in central Canada, the University of Toronto Law Journal was one year old, an explicitly academic journal jointly published by faculty and students. ${ }^{16}$ It would survive to become an influential, faculty-run publication. With respect to English-language publications, the oldest academic journal was likely the Canadian Bar Review, which had started a decade earlier, in 1923. ${ }^{17}$ However, it was not an offshoot of a law school, the type of law review that Rodell railed against, but the official organ of a professional organization, the Canadian Bar Association.

In Canada the rush of university law reviews began after World War II. From 1947 to 1971 almost every law school ${ }^{18}$ established a journal, most of them run by students but some controlled by faculty. ${ }^{19}$ In 1947 students at the University of New Brunswick began a student-run review, ${ }^{20}$ and the publishing efforts of Toronto students were taking a more scholarly turn. ${ }^{21}$ By this time, however, there were dozens of American law reviews, many with long pedigrees. Their number and weight posed the distinct possibility that Canadian reviews would accept American reviews as their prototype. Indeed, at least one Canadian law school did so with deliberation and eagerness. At the University of British Columbia, which began UBC Legal Notes in 1949, early editors hoped that the journal would "grow to become a legal journal much in the nature of its cousins in the United States, the Harvard Law Review and the Yale Law Journal."22 Generally, the format of these post-war law reviews followed the Harvard model. Each issue would begin with a section containing signed articles by professors and practitioners, followed by comments

F.C. Cronkite, "Editorial" (1943) 8 Sask. Bar Rev. I. The two founding editors were Stuart Thom and David Tyerman. After the war Thom moved to Toronto and became a partner with Osler Haskins. Tyerman joined the Regina firm that still bears his name. McPherson. Leslie \& Tyerman - now Saskatchewan's largest.

16. The first issue of the University of Toronto Law Journal is dated Lent Term. 1935. The first volume has received a fine review by R.C.B. Risk. "Volume 1 of the Journal: $A$ Tributc and Belated Review" (1987) 37 U.T.L.J. 193.

The Canadian Bar Review merged two existing publications, the Canadian Law Times and the Canada Law Journal. See "Foreword by the President" (1923) I Can. Bar Rev. I.

18 Here are the exceptions. The Dalhousie Law Journal began in 1973, with five faculty and two students on the Editorial Committee. The Law Faculty at the University of Windsor began publishing the Windsor Yearbook of Access to Justice in 1981. The Faculty of Law, University of Calgary, does not publish its own review, but shares responsibility with the University of Alberta for the petroleum law issue of the Alberta Law Review. At the University of Victoria, students have published a student journal. Appeal, since 1995.

1) This generalization may be erroneous because journals often do not indicate whether. and to what extent, students and faculty share managing duties.

21" (1947) 1 U.N.B.L.J.

21 Volume 1 of the School of Law Review is dated December 11. 1942. It is the successor to The Court Crier, a mimeographed student newsletter that first appeared in 1937. It evolved into a more typical law review, changing its name to the Faculty of Law Review - University of Toronto in 1956. with Volume 14.

22 "Editorial" (1955) 2 U.B.C.Legal N. The editorial notes the aspirations of the founding editors six years earlier, declaring that the current editors "have not lost sight of the initial objective set by their predecessors of founding a first class legal periodical to promote legal learning and thus enhance the prestige of our law school". 
and articles written by students. Perhaps in a bow to more egalitarian sensibilities, Canadian reviews usually permitted student authors to sign their contributions.

\section{B. EXISTENTIAL ANGST}

The seething mass of American reviews may account partly for the existential angst that accompanied the birth of many Canadian reviews. At several journals, founding editors worried about the wisdom of publishing another law review. For instance, when the Manitoba Law School Journal appeared in 1962, its preface announced a focus on Manitoba issues and writers because " $[t] 0$ do otherwise would be to engage in fruitless competition with the already too numerous periodicals whose chief appeal is national or international. It is hoped that the Journal can be regional without being provincial." ${ }^{23}$ In a similar vein, when the Dalhousie Law Journal began in 1973, its inaugural editors remarked defensively: "You may ask why Canada needs yet another law journal." ${ }^{24}$ By this time there were about 15 journals sponsored by law schools, and an almost equal number by other organizations. It was not, the editors assured us, questions of prestige alone that compelled Dalhousie to publish a journal ( 90 years after the law school itself was established) but simply to encourage creative research and writing. "[T]he chief function of a legal periodical is to supply a forum for the exchange of opposing views." 25

\section{Canada's UniQue EXPerience}

\section{A. BILINGUAliSM AND BIJURIDICALISM}

One striking feature of early Canadian law reviews sets them apart from their American cousins. In the post-war period Quebec schools also began publishing law reviews, perhaps indicating that they felt similar pressures as the common law schools to include law reviews within their educational mission. ${ }^{26}$ But they published in French and wrote about the Civil Code. The University of Montreal, which had established its law school in 1852, began publishing Themis, a student journal, in April 1951. Its editors, at least, saw the journal as a necessity. "THEMIS n'est pas le fruit d'une génération spontanée. Sa présence au sein de notre Faculté s'est affirmée peu à peu comme une nécessité."27 At the University of Laval, students began publishing Les Cahiers de droit in $1954 .^{28} \mathrm{Ten}$

R.D. Gibson, "Preface" (1962-65) । Man. L. Sch. J. I [emphasis added]. In taking seriously the aspiration to carve a niche in a crowded market, the second issue reproduced a poem by a "Toronto poet," Margaret Atwood, because the editor thought it contained imagery "appropriate to the perennially controversial problem of defining the role of law in a "changing world."' See Editor's Note for Margaret Atwood, "The Dwarf" (1962-65) I Man. L. Sch. J. 146. The Journal changed its name in 1966 to the Manitoba Law Journal, taking a name that been dormant since the demise of a short-lived professional publication, the Manitoba Law Journal, which appeared from 1884-1885. "Foreword" (1973-74) I Dal. L.J. 2.

Ibid. The need to justify creating a journal may show that Canadians still did not expect law schools to automatically publish journals.

Scholarly publications in Quebec had been emanating from commercial publishers for some time; the first issue of La Revue Légale is dated May 15, 1869.

G. Lahaise, "Editorial" (1951-52) 1-2 Themis 5.

L. Bolduc, "Présentation" (1954-55) I C. de D. 6. 
years later, in 1964, the Section de droit civil at the University of Ottawa began publishing a journal, Justinien, changing the name to the Revue générale de droit in 1970. As well, in 1970 the University of Sherbrooke began Revue de Droit, sixteen years after the faculty was established in 1954, the Dean commenting that the review was a new stage in the school's development. ${ }^{29}$

Moreover, at the common law schools, editors of many new journals were well aware of the bilingual and bijuridical nature of Canada. They looked beyond the jurisdictions in which they resided and saw their mission as responding to both legal communities, perhaps even bridging a cultural divide. They wanted to include articles about both legal systems and to publish articles in English and French. Maybe the Canadian Bar Review had set the benchmark. In its first issue in 1923, the editors suggested that articles be sent "devoted to a comparative study of the two great systems of law operative in Canada," with a view to developing a "new and homogenous system of law" that would incorporate the merits of the common law and civil law. ${ }^{30}$ The editors were unabashedly patriotic. If this goal were achieved, "there would be an end to the unpatriotic and inept talk that one system should be rooted up and the other transplanted in its place." ${ }^{31}$ True to its word, the first issue published an article in English that compared Quebec law to that in other provinces ${ }^{32}$ and another one in French about the uniformity of laws. ${ }^{33}$

Perhaps partly because of the Canadian Bar Review's example, the university journals also sought to represent both legal systems. The first issue of the University of Toronto Law Journal declared its intention to include contributions on comparative law, "for which Quebec provides such ample initial scope." ${ }^{34}$ In line with that goal, it contained an article in French on the Civil Code. ${ }^{35}$ This goal is also evident in the first issue of the McGill Law Journal, which appeared several decades later in 1952. Noting that McGill was the only law school that taught civil law in the English language, the editors hoped that the Journal's emphasis on legal problems peculiar to Quebec would make "McGill's potential contribution to a better mutual understanding unique." ${ }^{36}$ And in the next decade, when the Common Law Section of the University of Ottawa published the first volume of its review in 1966, the Dean talked about the Review's goal of "transcending the confines of the common law and the civil law to an extent greater than is perhaps possible with many other common-law school reviews." ${ }^{37}$ Moreover, in 1970 when the section de droit civil changed the name of Justinien to Revue générale de droit, it did so to capture more

M. Guy, "Avant-propos" (1970) I R.D.U.S. vii.

"Salutatory" (1923) I Can. Bar Rev. 6 at 8.

Ibid. at 9.

F.A. Anglin, "Some Differences Between the Law of Quebec and the Law as Administered in the Other Provinces of Canada" (1923) I Can. Bar Rev. 33.

E.F. Surveyer, "L’Association du Barreau Canadien et L'Uniformite des Lois" (1923) I Can. Bar Rev. 52.

W.P.M. Kennedy, "Foreward" (1935) I U.T.L.J. 1 at 2.

P.B. Mignault, "Le Code Civil de la Province de Québec et son Interprétation" (1935) I U.T.L.J. 104.

"Foreword" (1952) I McGill L.J.

T.G. Feeney, “Dean's Forward" (1966) I Ottawa L. Rev. vii at viii. 
accurately the journal's practice of including not only articles about Quebec civil law, but also "du droit canadien et des droits étrangers." 38

Some journals did not specifically recognize their mission as representing, sampling, or bridging the distinctive dual nature of the Canadian legal system. Nevertheless, they pursued that goal. For instance, while the inaugural editors of Dalhousie Law Journal did not explicitly describe their mandate as bridging the civil law and common law traditions, the first article of their new journal was in French and dealt with comparative law. ${ }^{39}$

Today in law reviews, this effort to reflect bilingualism and bijuridicalism continues, albeit haltingly and with different degrees of success. During the past five years in common law schools, almost every journal has published at least one article in French, and many include abstracts in both French and English.

\section{B. CONSTITUTIONAL ReFoRM}

Many early journals display another common strand. If you peruse their first issues, you will see that one substantive topic stands out - constitutional reform. Discussing constitutional matters is a persistent theme of Canadian public discourse, and it is perhaps a defining feature of Canadian identity. Here the Canadian law review mirrors the national debates, with many journals containing articles about this topic in their first issues. In 1936 the first issue of the Saskatchewan Bar Review contained a brief essay on constitutional reform, arguing in favour of abolition of appeals to the Privy Council. ${ }^{40}$ The first issue of the New Brunswick Law Journal included an opinion about the merits of Newfoundland joining Confederation. ${ }^{41}$ And in the first issue of the University of Toronto Law Journal, V.C. MacDonald's now-classic essay on constitutional interpretation appeared ${ }^{42}$ Much later, not much had changed, with the first issue of the Dalhousie Law Review in 1973 containing an article on the merits of an entrenched Bill of Rights. ${ }^{43}$

\section{ConClusions}

As you can see, my search for the fictional article about Saskatchewan's perpetuities law led me to many other journals. As I poked around the library, wiping the dust off inaugural volumes of Canadian law reviews and reading many of their articles, I grew increasingly fond of the university-based law review. For one thing, each issue has a gem that makes time spent reading it worthwhile. And then, like now, the journals give significant return for a small cost. These rewards are not merely that some students learn

$12 \quad$ V.C. MacDonald, "Judicial Interpretation of the Canadian Constitution" (1935) I U.T.L.J. 260

" D.A. Schmeiser, "The Case Against Entrenchment of a Canadian Bill of Rights" (1973) I Dal. L.J. 
about editing, and professors have an easier time getting published. When law reviews are based in law schools, they serve a larger purpose - they proclaim that law schools are not trade schools, but are citizens of the scholarly community and the broader public community, participating in contemporary debates. By their existence, law reviews remind us that law is not only a practice, but also an intellectual discipline and pursuit.

The geographical spread of law reviews, which has marked them since their origins in the 1930 s, also makes an egalitarian and nationalist statement. Law as a scholarly pursuit was not only for lawyers in Montreal and Toronto. Lawyers and students from more distant places, with different perspectives on the world, could also engage in the great debates about constitutional reform, the growth of statutory law, and other pressing public issues. They, too, could discuss legal theory. As I dug into the library's musty stacks of law reviews, I regretted the lack of a Newfoundland law school and, consequently, a Newfoundland law school journal. How interesting now it would be to read what Newfoundland law students and professors would have said about legal issues both before and after Confederation in 1949.

I, for one, would be sad to see the number of law reviews reduced. Any shakedown or downsizing would likely mean that the smaller regional schools lose theirs first. This would be unfortunate. Law reviews are a cultural narrative. They tell a story about law and lawyers, revealing much about prevailing norms in the legal culture. By disclosing the issues that lawyers at any moment find important about law, legal education, and the profession, they map the development of Canadian legal norms, at least the official ones. They do not tell the entire story about law and lawyers, but they are an important chapter. Unless we believe that professional norms preclude or extinguish every regional difference, we ought to encourage reviews from every corner of the country. Nor does it matter if the far-flung voices are not each unique, or substantially different from each other. Indeed, if law reviews share characteristicsand concerns, telling similar stories with regional twists, we may realize that our identity as Canadians is stronger than we think.

Another notable difference between Canadian and American law reviews is that while we have spent very little time talking about ours, Americans regularly engage in navelgazing about theirs. I would safely surmise that no other educational institution produces scholarly journals in the same quantity as law schools. Yet we have given scant attention to the law review as a genre, not studying it critically as a cultural phenomenon or tracing its origins and growth. By contrast, American journals regularly sponsor symposia about themselves. By the time Rodell wrote in 1936, the long-established tradition of American law reviews had produced an almost equally long-standing tradition of robust criticism. Rodell's essay itself is part of a forum on law reviews. But I could find barely any critical perusal, whether friendly or hostile, of law reviews in Canada. ${ }^{44}$ The fact that we do not ponder law reviews may signify a prevailing belief about the Canadian identity - we cannot engage in sustained or deep self-exam ination for fear of not finding one and falling apart. However, I believe that modest critical scrutiny would do no harm, and it is perhaps fitting that editors of the Alberta Law Review, the successor to the first student-run review in Canada, have organized this colloquy. 
Today I have told only a tiny bit of the story about law reviews. Much more historical excavation needs to be done, and likely will be done. University-based law reviews arose as part of a larger evolution of legal education, and as scholars dig deeper into the history of legal education, especially after World War II, one can hope for, and expect, more study of law reviews.

At this juncture, my limited inquiry generates the following hypothesis: Canadian law reviews mirror the main elements of Canadians as a people. They are relatively young, not very numerous, some of them are Quebecois, and many speak both French and English. They frequently discuss constitutional issues. They live next door to the United States and cannot fully avoid the influence of their American neighbours. The most visible and important differences between Canadian and American reviews stem from our bilinguilism and bijuridicalism. Some Canadian reviews publish mostly in French, some in English, and most try to publish, at least occasionally, in both languages. With law reviews, one sees the truth of a quip often made about Canada generally: the presence of Quebec makes us unique. In short, the Canadian law review is a microcosm of the Canadian identity.

I invite your critique of this hypothesis - write in law reviews, please, and footnotes are optional! I leave you with the apt words of the inaugural editors of the Osgoode Hall Law School Journal: "The most severe judgement is your indifference." 45 